\title{
Framework for mapping key areas for marine megafauna to inform Marine Spatial Planning: the Falkland Islands case study
}

Amélie A. Augé1,*, Maria P. Dias², Ben Lascelles ${ }^{2}$, Alastair M.M. Baylis ${ }^{1}$, Andy Black ${ }^{1}$, P. Dee Boersma ${ }^{3}$, Paulo Catry ${ }^{4}$, Sarah Crofts ${ }^{5}$, Filippo Galimberti ${ }^{6}$, Jose Pedro Granadeiro ${ }^{7}$, April Hedd ${ }^{8, \#, ~ K a t r i n ~}$ Ludynia $^{9,10,}{ }^{\wedge}$, Juan F. Masello ${ }^{10, \&}$, William Montevecchi ${ }^{8}$, Richard A. Phillips ${ }^{11}$, Klemens Pütz ${ }^{12}$, Petra Quillfeldt ${ }^{13}$, Ginger A. Rebstock ${ }^{3}$, Simona Sanvito ${ }^{6}$, lain J. Staniland ${ }^{11}$, Andrew Stanworth ${ }^{5}$, Dave Thompson ${ }^{14}$, Megan Tierney ${ }^{1}$, Philip N. Trathan ${ }^{11}$, John P. Croxall ${ }^{2}$

${ }^{1}$ South Atlantic Environmental Research Institute, Stanley, Falkland Islands

${ }^{2}$ BirdLife International, The David Attenborough Building, Pembroke Street, Cambridge, CB2 3QZ,UK

${ }^{3}$ Department of Biology, University of Washington, Seattle, WA, USA

${ }^{4}$ MARE - Marine and Environmental Sciences Center, ISPA-Instituto Universitário, Lisboa, Portugal

${ }^{5}$ Falklands Conservation, Stanley, Falkland Islands

${ }^{6}$ Elephant Seal Research Group, Sea Lion Island, Falkland Islands

${ }^{7}$ CESAM, Departmento de Biologia Animal, Faculdade de Ciências, Universidade de Lisboa, Portugal

8 Psychology Department, Memorial University, St. John's, NL, Canada

${ }^{9}$ Department of Biological Sciences, University of Cape Town, South Africa

${ }^{10}$ Max Planck Institute for Ornithology, Vogelwarte Radolfzell, Radolfzell, Germany

${ }^{11}$ British Antarctic Survey, Natural Environment Research Council, High Cross, Madingley Road, Cambridge CB3 0ET, UK

12 Antarctic Research Trust, Am Oste-Hamme-Kanal 10, 27432 Bremervörde, Germany

13 Department of Animal Ecology \& Systematics, Justus Liebig University, Giessen, Germany

${ }^{14}$ Scottish Oceans Institute, University of St Andrews, St Andrews, UK

*Corresponding author Email amelie.auge@gmail.com Current address: Department of Conservation, Whangarei , New Zealand

\# Current address: Wildlife Research Division, Environment and Climate Change Canada, Mount Pearl, NL, Canada

${ }^{\wedge}$ Current address: SANCCOB, Cape Town, South Africa

\& Current address: Justus Liebig University Giessen, Department of Animal Ecology \& Systematics, Giessen, Germany 


\begin{abstract}
:
Marine Spatial Planning (MSP) is becoming a key management approach throughout the world. The process includes the mapping of how humans and wildlife use the marine environment to inform the development of management measures. An integrated multi-species approach to identifying key areas is important for MSP because it allows managers a global representation of an area, enabling them to see where management can have the most impact for biodiversity protection. However, multi-species analysis remains challenging. This paper presents a methodological framework for mapping key areas for marine megafauna (seabirds, pinnipeds, cetaceans) by incorporating different data types across multiple species. The framework includes analyses of tracking data and observation survey data, applying analytical steps according to the type of data available during each year quarter for each species. It produces core-use area layers at the species level, then combines these layers to create megafauna core-use area layers. The framework was applied in the Falkland Islands. The study gathered over 750,000 tracking and at-sea observation locations covering an equivalent of 5,495 data days between 1998 and 2015 for 36 species. The framework provides a step-by-step implementation protocol, replicable across geographic scales and transferable to multiple taxa. R scripts are provided. Common repositories, such as the Birdlife International Tracking Database, are invaluable tools, providing a secure platform for storing and accessing spatial data to apply the methodological framework. This provides managers with data necessary to enhance MSP efforts and marine conservation worldwide.
\end{abstract}

Keywords: marine conservation, MSP, Patagonian Shelf, seabirds, seals, South Atlantic, tracking data 


\section{Introduction}

Marine ecosystems worldwide face increasing pressures from maritime activities, coastal development, resource exploitation and pollution that threaten ecosystem health and biodiversity, and require a holistic management approach to mitigate threats (Douvere 2008; Halpern et al. 2008; Maxwell et al. 2013). During the last decade, the use of Marine Spatial Planning (MSP) to inform sustainable development and protection of the marine environment has grown worldwide (Ehler and Douvere 2010; Halpern et al. 2012; Flannery and Ó Cinnéide 2012; Merrie and Olsson 2014). MSP provides a spatial context for managing and planning the coordination of human uses of the sea. Spatial data are therefore one of the critical building blocks for MSP to map the physical environment, human activities, cultural values, and also distribution and habitat use of marine wildlife (Smith and Brennan 2012; Ban et al. 2013; Shucksmith et al. 2014; Caldow et al. 2015). Marine megafauna (here defined as seabirds, pinnipeds and cetaceans) have long been used as indicator species because their distributions reflect those of their prey, and potentially wider marine biodiversity and ecosystem processes (Hooker and Gerber 2004; Lewison et al. 2014). Hence, mapping key marine areas for these species can provide important inputs to MSP.

An increasing number of studies worldwide have investigated different approaches to analyse the available data and identify key areas for marine megafauna (also called important, priority conservation or critical areas; Gregr and Trites 2001; Bailey and Thompson 2009; Louzao et al. 2009; Wilson et al. 2009; Hedd et al. 2011; Camphuysen et al. 2012; Grecian et al. 2012; Lascelles et al. 2012; Le Corre et al. 2012; Montevecchi et al. 2012; McClellan et al. 2014; Camaclang et al. 2015; Flanders et al. 2015; Thiers et al. 2016; Soanes et al. 2016). Of particular importance, BirdLife International has developed a methodological framework to analyse and incorporate tracking data for multiple seabird species which can be used to define Important Bird and Biodiversity Areas (IBAs), both regionally and globally (Lascelles et al. 2016). Most studies focus only on identifying hotspots at the species level and few studies have attempted to present a standardised methodology that could be applied across taxa and seasons. An integrated multi-species approach to identifying key areas is important for MSP because it allows managers a global representation of an area, enabling them to see where management can have the most impact for biodiversity protection. However, multi-species analysis often requires the integration of data from different sources (such as at-sea observations and biologging data), which remains challenging.

Habitat modelling has been used to combine at-sea observations from ships and tracking data (e.g. Louzao et al. 2009). However, the time, resources and data required to undertake such analyses are often outside the scope of management organisations. Sufficient data required for such analyses are also available for only a very few species. It is evident that combining tracking and at-sea observation data improves knowledge of the ecological significance of marine areas (Camphuysen et al. 2012). Hence, a methodological framework that can combine multi-taxa tracking and observation data to map key areas in a repeatable and simple way would provide a valuable tool for MSP efforts. This paper presents a methodological framework that builds on the methodology of Lascelles et al. (2016) to analyse tracking data at the colony level, and incorporate these analyses within the framework which extrapolates results to other colonies and incorporates ship-based survey data. The framework incorporates data from a large number of species across seasons to define key areas for megafauna, and its steps and results are illustrated with a case study in the Falkland Islands.

The Patagonian Shelf surrounding the Falkland Islands is a productive and biodiversity-rich marine area (Glorioso 2002; Figure 1). Seventy seabird species and 29 marine mammal species have been recorded in Falkland Islands waters (White et al. 2002; Otley 2012). Most species are relatively well studied, and 17 species of seabirds and four pinnipeds have been tracked in these waters (48\% of common and regularly occurring species in Falkland Islands waters; Thompson et al. 1998, 2003; 
Pütz et al. 20002002a,b, 2003, 2006, 2014; Pütz 2002; Boersma et al. 2002; Huin 2002; Clausen and Pütz 2003; Campagna et al. 2007; Phillips et al. 2007; Masello et al. 2010, 2013, 2017; Hedd et al. 2012, 2014; Catry et al. 2013; Ludynia et al. 2013; Crofts et al. 2014; Ratcliffe et al. 2014; Baylis et al. 2015b, c; Quillfeldt et al. 2014, 2015, 2017). One third of the seabird species using the Falkland Islands waters breed on the Falkland Islands (Woods and Woods 1997). At least $17 \%$ of the marine mammals found in Falkland Islands waters breed there but knowledge of their distributions is currently limited. Falkland Islands waters are also important for a large number of migrants that breed elsewhere but visit the region during their non-breeding season or as juveniles (Croxall et al. 1999; Berrow et al. 2000; Croxall and Wood 2002; Nicholls et al. 2002; Nicholls et al. 2005; Falabella et al. 2009; Iñíguez et al. 2010; Otley 2012; Otley et al. 2012; Tancell et al. 2016). Due to the importance of the Patagonian Shelf for marine megafauna (Table 1) and the social and economic value accorded to these species, in particular for tourism and cultural identity (Augé 2015), the identification and mapping of their key areas is a priority for input into local MSP development.

[Figure 1 here]

The aims of the study were to develop the methodological framework that provides a consistent approach for mapping the intensity of use and species diversity for marine megafauna within a defined marine region. Part of the framework included the development of a scoring system for species and for data quality. The application of the framework to the Falkland Islands data produced:

a) A single map for 33 species of seabirds and 3 species of pinnipeds, reflecting their core-use areas in Falkland Islands waters throughout the year.

b) Composite maps illustrating the distribution of all marine megafauna (presenting a megafauna biodiversity index and a megafauna core use intensity index) in the marine area around the Falkland Islands by combining all species layers, with the use of a scoring system to reflect conservation and ecological importance.

The methodological framework is discussed in the context of applications to other areas and the results for the Falkland Islands are considered in the context of MSP and how they can later be used to assist this process.

\section{Material and Methods}

\subsection{Study area}

The study area is the Exclusive Economic Zone (EEZ) of the Falkland Islands, locally known as Falkland Islands Conservation Zone that covers $453,897 \mathrm{~km}^{2}$ of ocean around the islands (Figure 1). This area is administered by the Falkland Islands Government which includes the licensing of activities (e.g. fisheries, oil exploitation). All data analyses were conducted in the EEZ with an added 50-km buffer to avoid a boundary effect. Then, the results were clipped back to the EEZ for presentation. A grid of $10 \times 10 \mathrm{~km}$ cells was created for the entire study area and was used as a template for all results. Some results were produced at a coarser scale of $30 \times 30 \mathrm{~km}$ and resampled later based on this grid.

\subsection{Data collation and formatting}

The initial step of the framework is data search and collation, focusing on any spatial data available on the distribution of marine megafauna species occurring within the study area along with colony, life cycle and environmental data. The sections below describe sources, formatting and manipulation of these data for homogenisation across all species for our Falkland Islands case study.

\subsubsection{Tracking datasets}


Existing tracking data for seabirds and pinnipeds were identified from a range of sources, including scientific publications, published reports, the Atlas of the Patagonian Sea (Falabella et al. 2009), the list of all wildlife research permits provided by the Falkland Islands Government to scientists conducting work on the islands, and the BirdLife International Seabird Tracking Database (http://www.seabirdtracking.org/). The BirdLife database was used to house all additional tracking datasets obtained for seabirds as part of this study. Any tracking locations overlapping with the EEZ were included in the study (Appendix 1 summarises all identified datasets and their owners/providers and Appendix 2 the details of each dataset used in the analyses following data suitability assessment).

GPS (Global Positioning System), PTT (Platform Terminal Transmitter) and GLS (Global Location Sensing) should be considered in the context of the methodological framework described in this paper. However, after exploratory analyses we opted to use only GPS and PTT data for our case study in the Falkland Islands due to the large spatial error associated with GLS data (186 $\pm 114 \mathrm{~km}$; Phillips et al. 2004) in comparison to the size of the study area. Nevertheless for larger areas where GLS errors would satisfy assumptions, the same analytical steps can be applied to GLS data.

\subsubsection{At-sea observation datasets}

The main source of at-sea observations (ASO) data was the Joint Nature Conservation Committee (JNCC) large-scale surveys conducted from 1998 to 2001 throughout the EEZ of the Falkland Islands. These surveys followed the European Seabird At Sea (ESAS) protocol (White et al. 2002). Several other ASO datasets were found which consisted of opportunistic observations, or observations from fishing vessels or oil platforms; most had no effort data, were spatially-restricted or had records likely biased due to bird attraction (Bruce et al. 2005). Therefore, only the JNCC data were included in the study.

A total of 57 seabird species was recorded during the JNCC survey (50 species of flying seabirds; 7 species of penguins). The observation rate for pinnipeds and cetaceans was very low, so ASO data were not included for these species. Species classified as rare (i.e. few sightings) in White et al. (2002) were also excluded from the study due to the very low encounter rate, reducing the number of species with ASO data to 33 .

\subsubsection{Colony data}

Sizes (number of breeding pairs) and locations of penguin, albatross and giant petrel colonies were obtained from the latest island-wide census undertaken by Falklands Conservation as part of their long-term seabird monitoring programme (Falklands Conservation, unpublished data). Locations of breeding colonies of other species and breeding areas for those species with no distinct colonies (e.g. Magellanic penguins) were digitised from Woods and Woods (1997) as one point in each $10 \mathrm{x}$ $10 \mathrm{~km}$ cell, and population size estimated for sections of the coasts where the species is known to breed (at that $10 \times 10 \mathrm{~km}$ cell size). Pinniped colony locations and abundance (numbers of pups born) were obtained from Baylis et al. $(2014,2015 a)$ and the Elephant Seal Research Group (Filippo Galimberti, unpublished data).

\subsubsection{Bathymetry mask}

Bathymetry was obtained from the General Bathymetric Chart of the Oceans (GEBCO) dataset at a 4 $\mathrm{km}$ resolution (http://www.gebco.net/data and products/gridded bathymetry data/). Bathymetry values were extracted for each location along each individual foraging trip for each species. A 
bathymetric threshold was defined for each species as the depth beyond which $<1 \%$ of all available locations for that species were found. This threshold was used to create a species specific bathymetric mask that included only the areas where depth was less than that threshold.

\subsubsection{Annual life cycle table}

For species with tracking data, the timing of the different phases of the annual cycle was determined from available information on a weekly basis across the year. These data enabled calculation of the duration of each phase within each season or year and, in particular, indicated when animals breeding on the Falkland Islands are tied to their breeding colonies. The annual cycles for 11 species for which tracking data were available are illustrated in Figure 2 (Woods and Woods 1997; Galimberti and Boitani 1999; Pütz et al. 2001; Otley et al. 2004).

[Figure 2 here]

\subsection{Methodological framework}

The methodological framework involves producing year-quarter (YQ) layers for each species to generate a core-use index of the area by the species over that quarter. The quarters provide a temporal component to the analyses because the use of the marine environment varies greatly across seasons according to the life cycle (e.g. some species migrate out of the zone over winter). The quarters were designed to fit best the majority of the life cycles of species in the Falkland Islands and are YQ1 (December-February), YQ2 (March-May), YQ3 (June-August) and YQ4 (SeptemberNovember). Depending on the data (quantity and type) available for the species, the analytical steps set out below are taken (see Figure 3 for the conceptual model of the methodological framework). All the analytical steps were conducted in R 3.2. (R Core Team 2015). The R scripts for each step below can be found in the Supplementary Material provided with this paper.

[Figure 3 here]

\section{Step 1.1: Tracking data analyses}

When tracking data were available for a species during a life cycle stage, the type and amount of data were first assessed for suitability and representativeness. Tracking data were only used for analyses when at least 10 individual tracks were available for each stage of the annual life cycle for one colony, or 10 tracked animals for an entire species that does not breed in the Falkland Islands, or for a quarter when they do not use their breeding colonies.

The tracking data were formatted and standardised following the procedures provided at www.seabird.tracking.org (attributes required: (1) species, (2) colony, (3) stage of annual cycle, and (4) date-time), and split into datasets (unique combination of tracking data collected for each species' colony, in a certain breeding stage). The methodology described in details in Lascelles et al. (2016) was applied to each tracking dataset to calculate the core-use areas at sea of each individual. In summary, this consisted of 1) estimating the core-use area of each individual's foraging trip as the Kernel utilisation distribution $50 \%$ isopleths, then overlapping all trips to obtain the individual's core-use area - step batchUD in Lascelles et al. (2016); 2) mapping the intensity of use of each $10 \mathrm{x}$ $10 \mathrm{~km}$ grid cell within the area (expressed as \% of the population using each cell as their core-use area, hereafter \%birds; step polyCount in Lascelles et al. 2016). An example of the application of these functions to a dataset is illustrated in Figure $4 a, b$.

[Figure 4 here] 


\section{Step 1.2: Extrapolation to other colonies (without tracking data)}

The relationship between the percentage of the core-use areas used by each individual that fell within each cell, and the distance to the colony of origin was estimated using a modified Gompertz curve. The Gompertz curve models the relationship between distance from shore and the proportion of animals from the colony using the cell. The proportion of animals using each grid cell was calculated as an average across tracked colonies during each breeding stage for the species (Figure 4c). The Gompertz curve was used because it accounts for the principle of central place foraging ecology and provides a way to model the decrease in use from the colony point as an average function. The use of the Gompertz curve is conducted under the same assumptions as the foraging radius concept (maximum distance individuals reach at sea from the colony) that has been used in other studies (Grecian et al. 2012; Soanes et al 2016). The average function was then applied to all known colonies of each species without tracking data in another breeding stage, to create a map presenting the modelled percentage of animals' core-use areas of each colony covering each $10 \times 10$ $\mathrm{km}$ cell during each breeding stage, then represented after applying the bathymetric mask (Figures $4 d, 4 e)$.

\section{Step 1.3: Creation of the year-quarter layers from tracking data}

For each breeding stage, maps obtained for each colony were combined based on the percentage of the Falkland Islands population in each colony. This assigned the percentage of individuals of the entire population of the Falkland Islands that have core-use areas in each cell (Figure 4f). The layers were then standardised to obtain values from 0 to 100. Maps for each breeding stage were then combined to produce year-quarter layers by taking into account the overlap between each breeding stage and year quarters (see Figure 2). In the example of the black-browed albatross Thalassarche melanophris (Figure 5), YQ1 is made from the incubation stage (1 month), brood-guard stage (1 month), and the post-guard stage (1 month), so the final map for YQ1 was calculated with weighted average incubation $* 1 / 3+$ brood-guard $* 1 / 3+$ post-guard $* 1 / 3$.

[Figure 5 here]

\section{Step 1.4: Creation of the year-quarter layers from At Sea Observation data}

When no tracking data were available for a species during one quarter, the distribution of the species was mapped using the ASO data. The grid cell size for analysis was defined to minimize the number of empty cells (i.e., cells with no sampling effort) and maximize the number of ASO unit samples per cell, without oversimplifying the final result. After testing the size chosen was $30 \mathrm{~km}$ * $30 \mathrm{~km}$ (i.e. similar to the size used by White et al. [2002]). To create quarter layers the steps were (a) Calculate the density of birds (dens; birds $/ \mathrm{km}^{2}$ ) based on the $300 \times 300 \mathrm{~m}$ cell sampling effort unit (see (White et al. 2002) for more details), taking into consideration the counts of 0 where effort occurred but no animals of that species were seen; (b) Average the density values within each $30 \mathrm{~km}$ * $30 \mathrm{~km}$ grid cell; (c) Apply an interpolation modelling (kriging with function krige, R package gstat with a value equivalent to the average radius of the core area as per methodology in Lascelles et al. [2016]) to fill in values of cells with no effort; (d) Standardise the values to a 0-100 scale, based on the maximum density value (after logarithmic transformation).

This step produced the remaining quarter layers from ASO data and, after this step, each species had 4 quarter layers, each assigned a data type (tracking or ASO). Examples of quarter layers for 3 selected species (a long-range flying seabird, a short-range penguin and a pinniped) are shown in Figure 5. 
The year-quarter layers for each species were combined in this step to produce a single species-layer using the quarter scores comprising two types of weights: data type and Intensity of use. Data from tracking were given twice as much weight as ASO data because ASO data were one-off sightings during single surveys that could have been affected by local short-term environmental conditions more than the tracking data. The relative intensity of use of the Falkland Islands waters by a species during each quarter, in comparison to other quarters, was classified using the ratio of the highest density value (in number of individuals per $\mathrm{km}^{2}$ ) of the quarter compared to the highest value across all quarters as calculated from the analyses of the JNCC ASO data for the seabird species with the classification (weight from 0 to 3, respectively): Almost none (<0.01), Low (0.01-0.2), Medium (0.20.5 ) and High (0.5-1). For pinniped species, weights for intensity of use were all given the same value of 1 for all quarters. The weights for both criteria were multiplied to give a final quarter score. Appendix 3 contains the weights and final quarter scores for each quarter of each species. We calculated these layers with weighted averages using the final quarter scores applied to each related quarter of the species. Each species layer maps the intensity of use of each $10 * 10 \mathrm{~km}$ cell by the species across the year, with the value defined as the intensity use index.

\section{Step 3: Combining species layers to megafauna layers}

The megafauna key area layers were created by averaging the values across all 36 species layers. The species layers, however, all depict the relative and standardised use for the species, and do not reflect either conservation (threat status) or ecological (numbers or biomass) importance. Therefore, two options to create megafauna layers using a scoring system reflecting the characteristics of each species are also presented (Table 2). The scores were applied to the species layers to calculate: 1 . a conservation-focus megafauna key area layer (with scores based on IUCN status, irreplaceability and data quality); and 2. an ecologically-focussed megafauna key area layer (with scores based on population estimate, average individual mass and number of year-quarters present in Falkland Islands waters). The two scoring systems were created, respectively, based on a sample of simplified IUCN's Key Biodiversity Area criteria and categories (IUCN 2016) that were edited from consultation and agreement with the Falkland Islands environmental managers, and based on the biomass concept (number of individuals multiplied by the average mass). The similarity of indices between the two scoring systems was assessed with a Pearson correlation coefficient $\left(R^{2}\right)$.

The megafauna layers were created from the weighted average across all species using the respective scores as weights. The conservation and ecological scores assigned to each species are provided in Appendix 4. These two scored layers can be compared to determine if the identified key areas are similarly highlighted in both resulting maps (using the top $10 \%$ and $20 \%$ of the cell values in each map).

A biodiversity richness index was also mapped using the species layers. Values of over $50 \%$ (therefore capturing the cells that an estimated half of the population of the species uses across the year) were selected in each species layer to create a core-use polygon for each species. The number of species core-use areas overlapping each cell was summed to calculate a megafauna biodiversity richness index.

\section{Results}

\subsection{Species layers}


The methodological framework was applied to 36 species ( 33 seabirds; 3 pinnipeds). In total, the chosen methodology for each species (across the four quarters) corresponded to ASO only (16), tracking only (3), tracking + ASO (8), tracking + extrapolation (5), tracking + extrapolation + ASO (4) (see Table 1). Appendix 2 describes in details all the tracking datasets collated in this study and included in the analyses. In total, the analyses included 591,003 tracking locations covering a total of 5,495 data days between 1998 and 2015. The ASO data analysed were made of 157,700 recorded locations of observations of seabirds over a 4-year period. All species layers can be visualised online on a custom-made Falkland Islands Marine Spatial Planning webGIS focussed on marine megafauna at the link:

http://148.251.22.181/saeri webgis/lizmap/www/index.php/view/map/?repository=v05\&project=w ebGIS20160801

\subsection{Megafauna layers}

The megafauna key area layers (conservation and ecological) give an overview of the distribution of use of the Falkland Islands EEZ by marine megafauna using two sets of criteria (Figure 6). The index ranges from 0 to 1 and depicts the intensity of use by all species, based on the species layers. The conservation and ecological key area layers harbour similar overall patterns of distribution of usage by all species with a high similarity between conservation and ecological index values for each cell $\left(R^{2}=0.95 ;\right.$ Appendix 5). The overall pattern of distribution of the high value core-use areas remained similar with the different set of scores, in particular when selecting the cells with the highest index values covering $10 \%$ of the Falkland Islands EEZ (Figure 7). This indicates that both conservation and ecological importance follow a similar pattern of distribution. The key areas are the near-shore and coastal areas. The overlap between the top areas based on the different scores is, however, lower when selecting the cells with the highest index value covering $20 \%$ of the EEZ.

[Figure 6 here]

[Figure 7 here]

The megafauna species richness layer displays a Biodiversity Index that is the total number of coreuse areas of the 36 species that overlapped with each 10-km cell across the year (Figure 8). A similar pattern to the key areas emerged with the coastal areas displaying the highest values (up to 20 species with core-use areas in one cell), while the offshore area east of the islands has very low values of one or two species only. No cell had a value of 0 .

[Figure 8 here]

\section{Discussion}

This paper presents a methodological framework to map the spatial use patterns of marine megafauna and to identify key areas. Crucially, the framework enables the inclusion of multiple taxa, different types of data (associated with different degrees of error), uses a simple extrapolation model to include non-studied colonies, and retains species information in the form of intermediate species layers (breeding stage, quarter and species layers). In summary, the framework constitutes seven steps: 1) study area definition, 2) data collation, 3) data classification and formatting, 4) species-level analyses by year-quarter (using decision tree and methodology summarised in Figure $3), 5$ ) creation of layers indicating intensity of use by each species, 6) species scoring, 7) creation of megafauna layers (eg. biodiversity and core-use intensity). The resulting maps can be incorporated as a decision-support tool or in spatial and prioritisation analyses for MSP. The methodological framework, combined with simple data formatting and R scripts will enable updates with minimal 
resources in terms of time when new data are available, which is essential as part of the regular recommended review required in assessing the continued efficiency of MSP.

The framework was applied to the most common species of marine megafauna within the Falkland Islands EEZ. The process of identifying and gathering data for numerous species across many providers was streamlined by the use of the Birdlife International Tracking Database. Data providers had the assurance that their data would be shared and used only for specific analyses towards marine conservation improvement goals due to well established legal protocols, agreements and data protection of this database. This was very successful in obtaining a large dataset with information for 36 species. The megafauna maps are illustrative of the final products from the methodological framework. In particular, the conservation key area layer and the species richness layer could be used in the context of MSP to (1) identify areas for potential protection of key sites for multiple species (e.g. areas with the highest values for the conservation or biodiversity indices; Worm et al. 2003), (2) manage particular activities (e.g. shipping, oil extraction) within highlighted key areas to minimise their impacts, (3) identify areas that require more detailed assessments or more stringent requirements in terms of Environmental Impact Assessments (EIAs) if new developments are proposed. The ecological key area layer, on the other hand, could be used in the context of wider fishery spatial management and potential impacts on megafauna food resources through increased understanding of energy transfer in the marine systems underlying the MSP effort. The intermediate species layers produced during the process can also be used for finer-scale studies on single species in the context of EIA or risk assessments from current or proposed activities or development, for cumulative impact analyses for MSP, and for identification of major gaps in data availability and research needs. The framework therefore provides a series of layers depicting the use of a study area by marine megafauna. Decision makers can use them to inform MSP analyses and to design a range of management options as part of MSP, for example shipping lanes to avoid areas with highest concentration, or designating a network of Marine Protected Areas (MPAs).

It is, however, important to emphasise that, depending on the intended application, managers would need to review the criteria and assumptions involved in the results presented for the Falkland Islands to understand the potential biases due to data availability, criteria and score choices. For example, while the scoring criteria and the weights used to create the conservation key area layer were based on internationally-accepted guidelines and had inputs from local managers, there may be other local criteria for conservation and distribution of weights that should be explored prior to application (eg. cultural significance, national red list, importance for tourism). In addition, the treatment of raw location data is simplified to allow integration of a wide variety of data types. While basic data quality is included as a weight within the framework, there is scope to add a parallel analysis to produce a simple way of mapping data accuracy and to assess whether tracking data is representative for each species or colony (e.g. nonlinear asymptotic regression analysis, previously used by Lascelles et al. 2016, Soanes et al 2013; Maxwell et al. 2016). This would give managers an easily understood visual way of assessing potential risks associated with their decisions for MSP due to uncertainty from the raw location data fed in the framework (e.g., Johnsen et al. 2008). Finally, the Falkland Islands is one of the most data-rich parts of the ocean in terms of marine megafauna, with the exception of cetaceans for which data are deficient. Therefore cetaceans were not included in the analysis presented here (but the methodological framework was designed to incorporate cetacean data when available). The Falkland Islands is an important habitat for migrating baleen whales and resident delphinids (Iñíguez et al., 2010; Otley, 2012). When data become available for these species, their integration in the methodological framework will be possible for future MSP review. Integrating cetacean distribution data will be particularly important as whale populations worldwide are recovering and whale sightings have been increasing around the Falkland Islands in the last decades (Frans and Augé 2016). Therefore, efforts are required to obtain fine-scale 
distribution data for cetaceans for incorporation into the framework and for MSP efforts in the Falkland Islands.

The range of scoring criteria presented in this study is given as a general guide. The criteria and their weights were developed for the Falkland Islands, from consultation with stakeholders and managers for an MSP application towards identifying potential areas for protection. Criteria need to be customised for specific practical MSP applications. Therefore, the application of the methodological framework in the Falkland Islands and other regions with different sets of species, and different MSP or conservation aims, will need to include the step of creating scoring criteria. Methodology to define a scoring system will be region-specific and the decision should be made by managers with advice from expert knowledge for defining thresholds. For the Falkland Islands case study, two scoring options are presented for the species layers to illustrate the impacts of using alternative criteria in generating the final layers, and how the results could be used for different aspects of MSP. The areas with the highest index of density use were consistent across scoring systems; the areas with lower values did vary between scoring systems. Managers, however, often require the identification of key areas (i.e. areas with an index of highest values) and therefore the differences should not affect the utility of the framework for the identification of key areas.

The results of the application of the framework to the Falkland Islands indicated that the key areas for marine megafauna included all coastal waters around the islands and, overall, the shallower areas $(<200 \mathrm{~m}$ depth). This is mostly due to the large concentration of breeding colonies of seabirds and pinnipeds on the islands. The pattern was consistent with both scoring systems, whereas there is almost no correlation between the scores calculated for each species in the two scoring systems. The coastal areas around breeding colonies are where the highest concentration of animals occurs because individuals of the colony must use this area (for rafting before returning to nest in flying seabirds, and for accessing the breeding or hauling out areas for pinnipeds and penguins). A recent study has also highlighted the importance of near-shore areas for black-browed albatross spending significant time on near-shore waters before departing to sea (Granadeiro et al 2017). Other studies have also shown that coastal areas are often key areas for marine megafauna (Péron et al. 2013; McClellan et al. 2014; Thiers et al. 2016). It is, however, also important to note that, for wide ranging species (for instance southern elephant seals), the overall species core use areas may be found outside of the Falkland Islands EEZ most of the year. MSP within a country's waters can improve sustainable marine management and conservation at the national level. Nonetheless, for protection of wide-ranging species to be effective, cross-nation MSP will also be required. The framework presented here could provide a way to conduct analyses to inform cross-nation MSP.

\section{Conclusion}

In conclusion, this paper presents a replicable simple methodological framework that incorporates a wide range of data types to map megafauna key areas. The illustration of this framework in the Falkland Islands demonstrated its applicability and potential uses for MSP while highlighting its limitations that managers need to understand. The methodological framework provides a simple step-by-step implementation protocol, replicable across geographic scales and transferable to multiple taxa. The results of the framework provide a range of spatial tools for MSP and decision support tools for marine management and opportunities. New data can be added relatively easily to re-run the analyses during MSP review process for instance. Other areas of the world have sufficient data to apply such a framework for creating maps to inform MSP (e.g., Bay of Biscay, Pettex et al. 2017, or other UK Overseas Territories). Gathering the data available is, however, still an obstacle for such studies. It can be very time-consuming and difficult to find where data are stored and who to contact, in particular for tracking data from species that use but do not breed in an area, from wideranging species, or data from scattered at-sea surveys that may be conducted by consultants, 
researchers or tourism operators. Initiatives such as the Birdlife International Tracking Database will provide invaluable tools for this step in the future. Funding agencies, universities and governments should ensure that data are stored and made available in such a database to provide required data for the success of MSP efforts and to improve marine conservation worldwide.

\section{ACKNOWLEDGMENTS}

This study was funded by the Department for Environment, Food and Rural Affairs UK as part of the Darwin Plus project DPLUS027 (Marine Spatial Planning for the Falkland Islands). We thank many people for their contributions to this paper, for attending the workshop in Cambridge, UK (report of the workshop where this paper originated can be found at http://www.south-atlanticresearch.org/media/files/MSP Falkands Framing-Workshop-report 5-7 April 2016 FINAL.pdf), or for providing data, in particular Nick Rendell (Environmental Planning Department, Falkland Islands Government), Norman Ratcliffe (British Antarctic Survey), and Mary-Anne Lea (University of Tasmania). We also acknowledge many others for their general contributions and dedication to the conservation efforts in the study area, in particular Claudio Campagna and Valeria Falabella (Wildlife Conservation Society) and lan Strange (New Island Conservation Trust). We also give recognition to all the field workers who were involved in gathering the data we used in this study; highest credit to you all. Acknowledgment also goes to iLaria Marengo (SAERI) for implementing the webGIS interface. The MSP project steering committee provided advice and directions with the wider MSP initiation context throughout the project, thanks to Paul Brickle (SAERI) for initially securing funding for the MSP project. The Falkland Islands Government provided support towards the acquisition of many datasets and assistance during this study. JFM received financial support during this study from the German Research Foundation (DFG SPP 1158, MA2574/6-1). JPG received financial support during this study from FCT - Portugal through the strategic project UID/AMB/ 50017/2013 and from FEDER funds granted to CESAM, within the PT2020 Partnership Agreement and Compete 2020. Two anonymous reviewers, the editor and Veronica Frans provided helpful reviews and suggestions to improve the manuscript. 


\section{REFERENCES}

Augé A (2015) Marine spatial planning for the Falkland Islands. "Setting the scene" workshop report. South Atlantic Environmental Research Institute, Stanley, Falkland Islands. Available at http://www.south-atlanticresearch.org/media/files/MSP\%20Workshop\%231\%20report\%20 Setting\%20the\%20scene \%2024-25\%20November\%202014.pdf (retrieved 29/10/17)

Bailey $\mathrm{H}$, Thompson PM (2009) Using marine mammal habitat modelling to identify priority conservation zones within a marine protected area. Marine Ecology-Progress Series 378:279287.

Ban NC, Bodtker KM, Nicolson D, Robb CK, Royle K, Short C (2013) Setting the stage for marine spatial planning: Ecological and social data collation and analyses in Canada's Pacific waters. Marine Policy 39:11-20.

Baylis AMM, Arnould JP, Staniland IJ (2014) Diet of South American fur seals at the Falkland Islands. Marine Mammal Science 30:1210-1219.

Baylis AMM, Orben RA, Arnould JP, Christiansen F, Hays GC, Staniland IJ (2015a) Disentangling the cause of a catastrophic population decline in a large marine mammal. Ecology 96:2834-2847.

Baylis AMM, Orben RA, Pistorius P, Brickle P, Staniland I, Ratcliffe N (2015b) Winter foraging site fidelity of king penguins breeding at the Falkland Islands. Marine Biology 162:99-110.

Baylis AMM, Orben RA, Arnould JPY, Peters K, Knox T, Costa DP, Staniland IJ (2015c) Diving deeper into individual foraging specializations of a large marine predator, the southern sea lion. Oecologia 179:1053-1065.

Berrow SD, Wood AR, Prince PA (2000) Foraging location and range of White-chinned Petrels Procellaria aequinoctialis breeding in the South Atlantic. Journal of Avian Biology 31:303311.

Boersma PD, Stokes DL, Strange IJ (2002) Applying ecology to conservation: tracking breeding penguins at New Island South reserve, Falkland Islands. Aquatic Conservation: Marine and Freshwater Ecosystems 12:63-74.

Burke CM, Davoren GK, Montevecchi WA, Wiese FK (2005) Surveys of seabirds on support vessel transects and at oil platforms on the Grand Bank. Pages 587-614 in: P Cransford, K Lee (Editors). Offshore Oil and Gas Environmental Effects Monitoring. Battelle, Columbus, Ohio.

Caldow C, Monaco ME, Pittman SJ, Kendall MS, Goedeke TL, Menza C, Kinlan BP, Costa BM (2015) Biogeographic assessments: A framework for information synthesis in marine spatial planning. Marine Policy 51:423-432.

Camaclang AE, Maron M, Martin TG, Possingham HP (2015) Current practices in the identification of critical habitat for threatened species. Conservation Biology 29:482-492.

Campagna C, Piola AR, Marin MR, Lewis M, Zajaczkovski U, Fernández T (2007) Deep divers in shallow seas: Southern elephant seals on the Patagonian shelf. Deep Sea Research Part I: Oceanographic Research Papers 54:1792-1814. 
Camphuysen KC, Shamoun-Baranes J, Bouten W, Garthe S (2012) Identifying ecologically important marine areas for seabirds using behavioural information in combination with distribution patterns. Biological Conservation 156:22-29.

Catry P, Lemos RT, Brickle P, Phillips RA, Matias R, Granadeiro JP (2013) Predicting the distribution of a threatened albatross: The importance of competition, fisheries and annual variability. Progress in Oceanography 110:1-10.

Clausen A, Pütz K (2003) Winter diet and foraging range of gentoo penguins (Pygoscelis papua) from Kidney Cove, Falkland Islands. Polar Biology 26:32-40.

Crofts S, Reeves M, Stanworth A, Ratcliffe N (2014) Tracking imperial and rock shags at two islands (Middle Island and Steeple Jason) at the Falkland Islands - A summary report. Falklands Conservation, Stanley, Falkland Islands.

Croxall JP, Black AD, Wood AG (1999) Age, sex and status of wandering albatrosses Diomedea exulans L. in Falkland Islands waters. Antarctic Science 11:150-156.

Croxall JP, Wood AG (2002) The importance of the Patagonian Shelf for top predator species breeding at South Georgia. Aquatic Conservation-Marine and Freshwater Ecosystems 12:101-118.

Douvere $F(2008)$ The importance of marine spatial planning in advancing ecosystem-based sea use management. Marine Policy 32:762-771.

Ehler C, Douvere F (2010) An international perspective on marine spatial planning initiatives. Environments 37:9-20.

Falabella V, Campagna C, Croxall JP (2009) Atlas del Mar Patagonico: Especies y espacios. Wildlife Conservation and Birdlife International, Buenos Aires, Argentina. Available online at http://atlas-marpatagonico.org/index.html

Flanders NP, Gardner B, Winiarski KJ, Paton PW, Allison T, Connell AF (2015) Key seabird areas in southern New England identified using a community occupancy model. Marine Ecology Progress Series 533:277-290.

Flannery W, Ó Cinnéide M (2012) A roadmap for marine spatial planning: A critical examination of the European Commission's guiding principles based on their application in the Clyde MSP Pilot Project. Marine Policy 36:265-271.

Frans VF, Augé AA (2016). Use of local ecological knowledge to investigate endangered baleen whale recovery in the Falkland Islands. Biological Conservation 202:127-137.

Galimberti F, Boitani L (1999) Demography and breeding biology of a small, localized population of southern elephant seals (Mirounga leonina). Marine Mammal Science 15:159-178.

Glorioso PD (2002) Modelling the Southwest Atlantic. Aquatic Conservation: Marine and Freshwater Ecosystems 12:27-37.

Granadeiro JP, Campioni L, Catry P (2017) Albatrosses bathe before departing on a foraging trip: implications for risk assessments and marine spatial planning. Bird Conservation International DOI: https://doi.org/10.1017/S0959270916000459. 
Grecian WJ, Witt MJ, Attrill MJ, Bearhop S, Godley BJ, Grémillet D, Hamer KC, Votier SC (2012) A novel projection technique to identify important at-sea areas for seabird conservation: An example using northern gannets breeding in the North East Atlantic. Biological conservation 156:43-52.

Gregr EJ, Trites AW (2001) Predictions of critical habitat for five whale species in the waters of coastal British Columbia. Canadian Journal of Fisheries and Aquatic Sciences 58:1265-1285.

Halpern BS, Diamond J, Gaines S, Gelcich S, Gleason M, Jennings S, Lester S, Mace A, McCook L, McLeod K, Napoli N (2012) Near-term priorities for the science, policy and practice of Coastal and Marine Spatial Planning (CMSP). Marine Policy 36:198-205.

Halpern BS, McLeod KL, Rosenberg AA, Crowder LB (2008) Managing for cumulative impacts in ecosystem-based management through ocean zoning. Ocean and Coastal Management 51:203-211.

Hedd A, Montevecchi WA, McFarlane-Tranquilla L, Burke CM, Fifield DA, Robertson GJ, Phillips RA, Gjerdrum C, Regular PM (2011) Reducing uncertainty on the Grand Bank: Tracking and vessel surveys indicate mortality risks for Common Murres in the Northwest Atlantic. Animal Conservation 14: 630-641.

Hedd A, Montevecchi WA, Otley H, Phillips RA, Fifield DA (2012) Trans-equatorial migration and habitat use by sooty shearwaters Puffinus griseus from the South Atlantic during the nonbreeding season. Marine Ecology Progress Series 449:277-290.

Hedd A, Montevecchi WA, Phillips RA, Fifield DA (2014) Seasonal sexual segregation by monomorphic sooty shearwaters Puffinus griseus reflects different reproductive roles during the pre-laying period. PloS one 9:e85572.

Hooker SK, Gerber LR (2004) Marine reserves as a tool for ecosystem-based management: The potential importance of megafauna. BioScience 54:27-39.

Huin N (2002) Foraging distribution of the black-browed albatross, Thalassarche melanophris, breeding in the Falkland Islands. Aquatic Conservation: -Marine and Freshwater Ecosystems 12:89-99.

Iñíguez M, Masello JF, Gribaudo C, Arcucci D, Krohling F, Belgrano J (2010) On the occurrence of sei whales, Balaenoptera borealis, in the southwestern Atlantic. Marine Biodiversity Records 3:e68.

IUCN (2016). A Global Standard for the Identification of Key Biodiversity Areas, Version 1.0. First edition. Gland, Switzerland: IUCN. Available at https://portals.iucn.org/library/sites/library/files/documents/2016-048.pdf (retrieved $11 / 02 / 18)$

Lascelles BG, Langham GM, Ronconi RA, Reid JB (2012) From hotspots to site protection: Identifying marine protected areas for seabirds around the globe. Biological Conservation 156:5-14.

Lascelles BG, Taylor PR, Miller MGR, Dias MP, Oppel S, Torres L, Hedd A, Le Corre M, Phillips RA, Shaffer SA, Weimerskirch $H$ (2016) Applying global criteria to tracking data to define important areas for marine conservation. Diversity and Distributions 22:422-431. 
Le Corre M, Jaeger A, Pinet P, Kappes MA, Weimerskirch H, Catry T, Ramos JA, Russell JC, Shah N, Jaquemet $S$ (2012) Tracking seabirds to identify potential Marine Protected Areas in the tropical western Indian Ocean. Biological Conservation 156:83-93.

Lewison RL, Crowder LB, Wallace BP, Moore JE, Cox T, Zydelis R, McDonald S, DiMatteo A, Dunn DC, Kot CY, Bjorkland R (2014) Global patterns of marine mammal, seabird, and sea turtle bycatch reveal taxa-specific and cumulative megafauna hotspots. Proceedings of the National Academy of Sciences 111:5271-5276.

Louzao M, Bécares J, Rodríguez B, Hyrenbach KD, Ruiz A, Arcos JM (2009) Combining vessel-based surveys and tracking data to identify key marine areas for seabirds. Marine Ecology Progress Series 391:183-197.

Ludynia K, Dehnhard N, Poisbleau M, Demongin L, Masello JF, Voigt CC, Quillfeldt P (2013) Sexual segregation in rockhopper penguins during incubation. Animal Behaviour 85:255-267.

Masello JF, Mundry R, Poisbleau M, Demongin L, Voigt CC, Wikelski M, Quillfeldt P (2010) Diving seabirds share foraging space and time within and among species. Ecosphere 1:art19.

Masello JF, Wikelski M, Voigt CC, Quillfeldt P (2013) Distribution patterns predict individual specialization in the diet of dolphin gulls. PLoS ONE 8:e67714.

Masello JF, Kato A, Sommerfeld J, Mattern T, Quillfeldt, P (2017) How animals distribute themselves in space: variable energy landscapes. Frontiers in Zoology 14:1-14.

Maxwell SM, Hazen EL, Bograd SJ, Halpern BS, Breed GA, Nickel B, Teutschel NM, Crowder LB, Benson S, Dutton PH, Bailey H (2013) Cumulative human impacts on marine predators. Nature Communications 4:2688.

Maxwell SM, Conners MG, Sisson NB, Dawson TM (2016) Potential Benefits and Shortcomings of Marine Protected Areas for Small Seabirds Revealed Using Miniature Tags. Frontiers in Marine Science 3:264.

McClellan CM, Brereton T, Dell'Amico F, Johns DG, Cucknell AC, Patrick SC, Penrose R, Ridoux V, Solandt JL, Stephan E, Votier SC (2014) Understanding the distribution of marine megafauna in the English Channel region: Identifying key habitats for conservation within the busiest seaway on Earth. PloS one 9:e89720.

McFarlane Tranquilla LA, Montevecchi WA, Hedd A, Fifield DA, Burke CM, Smith PA, Regular PM, Robertson GJ, Gaston AJ, Phillips RA (2013) Multiple-colony winter habitat use by murres (Uria spp.) in the Northwest Atlantic Ocean: Implications for marine risk assessment. Marine Ecology Progress Series 472: 287-303

Merrie A, Olsson P (2014) An innovation and agency perspective on the emergence and spread of Marine Spatial Planning. Marine Policy 44:366-374.

Montevecchi WA, Hedd A, McFarlane Tranquilla L, Fifield DA, Burke CM, Regular PM, Davoren GK, Garthe S, Robertson GJ, Phillips RA (2012) Tracking seabirds to identify ecologically important and high risk marine areas in the western North Atlantic. Biological Conservation 156:62-71. 
Nicholls DG, Robertson CJR, Naef-Daenzer B (2005) Evaluating distribution modelling using kernel functions for northern royal albatrosses (Diomedea sanfordi) at sea off South America. Notornis 52:223.

Nicholls DG, Robertson CJR, Prince PA, Murray MD, Walker KJ, Elliott GP (2002) Foraging niches of three Diomedea albatrosses. Marine Ecology Progress Series 231:269-277.

Otley $\mathrm{H}$ (2012) The composition of the cetacean community in the Falkland (Malvinas) Islands, southwest South Atlantic Ocean. Revista de Biología Marina y Oceanografía 47:537-551.

Otley H, Smith J, Dalebout ML (2012) Beaked whale strandings on the Falkland Islands and South Georgia, South Atlantic Ocean, between 1866 and 2008. Journal of the Marine Biological Association U K 92:1851-1864.

Otley HM, Clausen AP, Christie DJ, Pütz K (2004) Aspects of the Breeding Biology of the Magellanic penguin in the Falkland Islands. Waterbirds 27:396-405.

Péron C, Grémillet D, Prudor A, Pettex E, Saraux C, Soriano-Redondo A, Authier M, Fort J (2013) Importance of coastal Marine Protected Areas for the conservation of pelagic seabirds: The case of Vulnerable yelkouan shearwaters in the Mediterranean Sea. Biological Conservation 168:210-221.

Pettex E, Laran S, Authier M, Blanck A, Dorémus G, Falchetto H, Lambert C, Monestiez P, Stéfan E, Van Canneyt O, Ridoux V (2017) Using large scale surveys to investigate seasonal variations in seabird distribution and abundance. Part II: The Bay of Biscay and the English Channel. Deep Sea Research Part II: Topical Studies in Oceanography 141:86-101.

Phillips RA, Catry P, Silk JR, Bearhop S, McGill R, Afanasyev V, Strange IJ (2007) Movements, winter distribution and activity patterns of Falkland and brown skuas: Insights from loggers and isotopes. Marine Ecology Progress Series 281-291.

Phillips RA, Silk JRD, Croxall JP, Afanasyev V, Briggs DR (2004) Accuracy of geolocation estimates for flying seabirds. Marine Ecology Progress Series 266:265-272.

Pütz K (2002) Spatial and temporal variability in the foraging areas of breeding king penguins. Condor 104:528-538.

Pütz K, Ingham RJ, Smith JG (2000) Satellite tracking of the winter migration of Magellanic penguins Spheniscus magellanicus breeding in the Falkland Islands. Ibis 142:614-622.

Pütz K, Ingham RJ, Smith JG (2002a) Foraging movements of Magellanic Penguins Spheniscus magellanicus during the breeding season in the Falkland Islands. Aquatic Conservation: Marine and Freshwater Ecosystems 12:75-87.

Pütz K, Ingham RJ, Smith JG, Croxall JP (2001) Population trends, breeding success and diet composition of gentoo Pygoscelis papua, Magellanic Spheniscus magellanicus and rockhopper Eudyptes chrysocome penguins in the Falkland Islands. Polar Biology 24:793-807.

Pütz K, Ingham RJ, Smith JG, Lüthi BH (2002b) Winter dispersal of rockhopper penguins Eudyptes chrysocome from the Falkland Islands and its implications for conservation. Marine Ecology Progress Series 240:273-284. 
Pütz K, Rey AR, Schiavini A, et al (2006) Winter migration of rockhopper penguins (Eudyptes $c$. chrysocome) breeding in the Southwest Atlantic: Is utilisation of different foraging areas reflected in opposing population trends? Polar Biology 29:735-744.

Pütz K, Smith JG, Ingham RJ, Lüthi BH (2003) Satellite tracking of male rockhopper penguins Eudyptes chrysocome during the incubation period at the Falkland Islands. Journal of Avian Biology 34:139-144.

Pütz K, Trathan PN, Pedrana J, Collins MA, Poncet S, Lüthi B (2014) Post-fledging dispersal of king penguins (Aptenodytes patagonicus) from two breeding sites in the South Atlantic. PloS one 9:e97164.

Quillfeldt P, Moodley Y, Weimerskirch H, Cherel Y, Delord K, Phillips R, Navarro J, Calderón L, Masello JF (2017) Does the genetic structure reflect differences in non-breeding movement? A case study in small, highly mobile seabirds. BMC Evolutionary Biology, 171:1-11.

$\mathrm{R}$ core Team (2015) A language and environment for statistical computing. R Foundation for Statistical Computing, Vienna, Austria. URL http://www.R-project.org/.

Ratcliffe N, Crofts S, Brown R, Baylis AM, Adlard S, Horswill C, Venables H, Taylor P, Trathan PN, Staniland IJ (2014) Love thy neighbour or opposites attract? Patterns of spatial segregation and association among crested penguin populations during winter. Journal of Biogeography 41:1183-1192.

Shucksmith R, Gray L, Kelly C, Tweddle JF (2014) Regional marine spatial planning - The data collection and mapping process. Marine Policy 50:1-9.

Smith G, Brennan RE (2012) Losing our way with mapping: Thinking critically about marine spatial planning in Scotland. Ocean and Coastal Management 69:210-216.

Soanes LM, Bright JA, Angel LP, Arnould JP, Bolton M, Berlincourt M, Lascelles B, Owen E, SimonBouhet B, Green JA (2016) Important foraging areas of seabirds from Anguilla, Caribbean: Implications for marine spatial planning. Marine Policy 70:85-92.

Soanes LM, Arnould JPY, Dodd SG, Sumner MD, Green JA (2013) How many seabirds do we need to track to define home-range area? Journal of Applied Ecology 50:671-679.

Tancell C, Sutherland WJ, Phillips RA (2016) Marine spatial planning for the conservation of albatrosses and large petrels breeding at South Georgia. Biological Conservation 198:165176.

Thiers L, Delord, Karine C, Bost CA, Guinet C, Weimerskirch H (2016) Important marine sectors for the top predator community around Kerguelen Archipelago. Polar Biology. doi: DOI 10.1007/s00300-016-1964-4.

Thompson D, Duck CD, McConnell BJ, Garrett J (1998) Foraging behaviour and diet of lactating female southern sea lions (Otaria flavescens) in the Falkland Islands. Journal of Zoology 246:135-146.

Thompson D, Moss SEW, Lovell P (2003) Foraging behaviour of South American fur seals Arctocephalus australis: Extracting fine scale foraging behaviour from satellite tracks. Marine Ecology Progress Series 260:285-296. 
White RW, Gillon KW, Black AD, Reid JB (2002) The distribution of seabirds and marine mammals in Falkland Islands waters. Joint Nature Conservation Council, Peterborough, UK.

Wilson LJ, McSorley CA, Gray CM, Dean BJ, Dunn TE, Webb A, Reid JB (2009) Radio-telemetry as a tool to define protected areas for seabirds in the marine environment. Biological Conservation 142:1808-1817.

Wood AG, Naef-Daenzer B, Prince P A, Croxall, JP (2000). Quantifying habitat use in satellite-tracked pelagic seabirds: application of kernel estimation to albatross locations. Journal of avian biology, 31:278-286.

Woods R, Woods A (1997) Atlas of breeding birds of the Falkland Islands. Anthony Nelson, Shropshire, England.

Worm B, Lotze HK, Myers RA (2003) Predator diversity hotspots in the blue ocean. Proceedings of the National Academy of Sciences 100:9884-9888. 
Table 1 Species included in the study and their IUCN status, breeding (if \% of world population is known and $>1 \%$, it is indicated in brackets), presence in the Falkland Islands' waters, and types of data available for modelling distribution (ASO: At-Sea Observation). * From Falabella et al. (2009) with smaller estimate used when range given; ${ }^{* *}$ From (White et al. 2002). For full description of tracking data ownership and deployment details used in this study, see Appendix 1 and Appendix 2

\begin{tabular}{|c|c|c|c|c|c|}
\hline $\begin{array}{l}\text { Species-Common } \\
\text { name }\end{array}$ & $\begin{array}{l}\text { Species - Latin } \\
\text { name }\end{array}$ & IUCN status & $\begin{array}{l}\text { Breeding in } \\
\text { Falklands* }\end{array}$ & $\begin{array}{l}\text { Presence in } \\
\text { Falklands* }\end{array}$ & Data available \\
\hline Atlantic petrel & Pterodroma incerta & EN & No & Regular & ASO \\
\hline $\begin{array}{l}\text { Black-bellied storm- } \\
\text { petrel }\end{array}$ & Fregetta tropica & LC & No & Regular & ASO \\
\hline $\begin{array}{l}\text { Black-browed } \\
\text { albatross }\end{array}$ & $\begin{array}{l}\text { Thalassarche } \\
\text { melanophris }\end{array}$ & NT & $\begin{array}{l}\text { Yes (76\% of } \\
\text { world pop.) }\end{array}$ & Common & $\begin{array}{l}\text { Tracking, } \\
\text { Colonies, ASO }\end{array}$ \\
\hline Blue petrel & Halobaena caerulea & LC & No & Regular & ASO \\
\hline Brown skua & $\begin{array}{l}\text { Stercorarius } \\
\text { antarcticus }\end{array}$ & LC & Yes & Common & Tracking, ASO \\
\hline Cape petrel & Daption capense & LC & No & Common & ASO \\
\hline $\begin{array}{l}\text { Common diving } \\
\text { petrel }\end{array}$ & $\begin{array}{l}\text { Pelecanoides } \\
\text { urinatrix }\end{array}$ & LC & Yes & Common & ASO \\
\hline Dolphin gull & $\begin{array}{l}\text { Leucophaeus } \\
\text { scoresbii }\end{array}$ & LC & $\begin{array}{l}\text { Yes ( } 30 \% \text { of } \\
\text { world pop.) }\end{array}$ & Scarce & Tracking, ASO \\
\hline Fairy prion & Pachyptila turtur & LC & Yes & Regular & ASO \\
\hline $\begin{array}{l}\text { Falkland steamer } \\
\text { duck }\end{array}$ & $\begin{array}{l}\text { Tachyeres } \\
\text { brachypterus }\end{array}$ & LC & $\begin{array}{l}\text { Yes (100\% of } \\
\text { world pop.) }\end{array}$ & Regular & ASO \\
\hline Gentoo penguin & Pygoscelis papua & NT & $\begin{array}{l}\text { Yes ( } 21 \% \text { of } \\
\text { world pop.) }\end{array}$ & Common & $\begin{array}{l}\text { Tracking, } \\
\text { Colonies, ASO }\end{array}$ \\
\hline Great shearwater & Puffinus gravis & LC & Yes & Common & ASO \\
\hline $\begin{array}{l}\text { Grey-backed storm- } \\
\text { petrel }\end{array}$ & Garrodia nereis & LC & Yes & Common & ASO \\
\hline $\begin{array}{l}\text { Grey-headed } \\
\text { albatross }\end{array}$ & $\begin{array}{l}\text { Thalassarche } \\
\text { chrysostoma }\end{array}$ & EN & No & Regular & Tracking, ASO \\
\hline Imperial shag & $\begin{array}{l}\text { Phalacrocorax } \\
\text { atriceps }\end{array}$ & LC & Yes (35\%) & Common & $\begin{array}{l}\text { Tracking, } \\
\text { Colonies, ASO }\end{array}$ \\
\hline Kelp gull & Larus dominicanus & $\mathrm{LC}$ & Yes & Common & ASO \\
\hline King penguin & $\begin{array}{l}\text { Aptenodytes } \\
\text { patagonicus }\end{array}$ & LC & Yes & Scarce & $\begin{array}{l}\text { Tracking, } \\
\text { Colonies, ASO }\end{array}$ \\
\hline Long-tailed jaeger & $\begin{array}{l}\text { Stercorarius } \\
\text { longicaudus }\end{array}$ & LC & No & Regular & ASO \\
\hline Magellanic penguin & $\begin{array}{l}\text { Spheniscus } \\
\text { magellanicus }\end{array}$ & NT & $\begin{array}{l}\text { Yes ( } 8 \% \text { of } \\
\text { world pop.) }\end{array}$ & Common & $\begin{array}{l}\text { Tracking, } \\
\text { Colonies, ASO }\end{array}$ \\
\hline $\begin{array}{l}\text { Northern giant } \\
\text { petrel }\end{array}$ & Macronectes halli & LC & No & Regular & Tracking, ASO \\
\hline $\begin{array}{l}\text { Northern royal } \\
\text { albatross }\end{array}$ & Diomedea sanfordi & EN & No & Regular & Tracking, ASO \\
\hline Rock shag & $\begin{array}{l}\text { Phalacrocorax } \\
\text { magellanicus }\end{array}$ & LC & $\begin{array}{l}\text { Yes ( } 5 \% \text { of } \\
\text { world pop.) }\end{array}$ & Regular & $\begin{array}{l}\text { Tracking, } \\
\text { Colonies, ASO }\end{array}$ \\
\hline Slender-billed prion & Pachyptila belcheri & LC & Yes & Common & ASO \\
\hline $\begin{array}{l}\text { Soft-plumaged } \\
\text { petrel }\end{array}$ & Pterodroma mollis & LC & No & Regular & ASO \\
\hline
\end{tabular}




\begin{tabular}{|c|c|c|c|c|c|}
\hline Sooty shearwater & Puffinus griseus & NT & Yes & Common & $\begin{array}{l}\text { Tracking, } \\
\text { Colonies, ASO }\end{array}$ \\
\hline $\begin{array}{l}\text { South American fur } \\
\text { seal }\end{array}$ & $\begin{array}{l}\text { Arctocephalus } \\
\text { australis }\end{array}$ & LC & $\begin{array}{l}\text { Yes ( } 4 \% \text { of } \\
\text { world pop.) }\end{array}$ & Common & $\begin{array}{l}\text { Tracking, } \\
\text { Colonies }\end{array}$ \\
\hline $\begin{array}{l}\text { South American } \\
\text { tern }\end{array}$ & $\begin{array}{l}\text { Sterna } \\
\text { hirundinacea }\end{array}$ & LC & Yes & Common & ASO \\
\hline $\begin{array}{l}\text { Southern elephant } \\
\text { seal }\end{array}$ & Mirounga leonine & LC & Yes & Common & $\begin{array}{l}\text { Tracking, } \\
\text { Colonies } \\
\end{array}$ \\
\hline Southern fulmar & $\begin{array}{l}\text { Fulmarus } \\
\text { glacialoides }\end{array}$ & LC & No & Common & ASO \\
\hline $\begin{array}{l}\text { Southern giant } \\
\text { petrel }\end{array}$ & $\begin{array}{l}\text { Macronectes } \\
\text { giganteus }\end{array}$ & LC & $\begin{array}{l}\text { Yes ( } 42 \% \text { of } \\
\text { world pop.) }\end{array}$ & Common & $\begin{array}{l}\text { Tracking, } \\
\text { Colonies, ASO }\end{array}$ \\
\hline $\begin{array}{l}\text { Southern } \\
\text { rockhopper } \\
\text { penguin } \\
\end{array}$ & $\begin{array}{l}\text { Eudyptes } \\
\text { chrysocome }\end{array}$ & VU & $\begin{array}{l}\text { Yes ( } 36 \% \text { of } \\
\text { world pop.) }\end{array}$ & Common & $\begin{array}{l}\text { Tracking, } \\
\text { Colonies, ASO }\end{array}$ \\
\hline $\begin{array}{l}\text { Southern royal } \\
\text { albatross }\end{array}$ & $\begin{array}{l}\text { Diomedea } \\
\text { epomophora }\end{array}$ & VU & No & Common & Tracking, ASO \\
\hline Southern sea lion & Otaria flavescens & LC & $\begin{array}{l}\text { Yes ( } 2 \% \text { of } \\
\text { world pop.) }\end{array}$ & Common & $\begin{array}{l}\text { Tracking, } \\
\text { Colonies }\end{array}$ \\
\hline $\begin{array}{l}\text { Wandering } \\
\text { albatross }\end{array}$ & Diomedea exulans & VU & No & Regular & Tracking, ASO \\
\hline $\begin{array}{l}\text { White-chinned } \\
\text { petrel }\end{array}$ & $\begin{array}{l}\text { Procellaria } \\
\text { aequinoctialis }\end{array}$ & VU & Yes & Common & Tracking, ASO \\
\hline $\begin{array}{l}\text { Wilson's storm- } \\
\text { petrel }\end{array}$ & $\begin{array}{l}\text { Oceanites } \\
\text { oceanicus }\end{array}$ & LC & Yes & Common & ASO \\
\hline
\end{tabular}


Table 2 Methodology to assign scores to species for combining species layers to a megafauna layer. The scores calculated for each species are available in Appendix 4. *Score value of 3 was skipped due to the significant difference in mass between the categories. "Critically endangered and endangered species were given the same value because they both require full protection for survival.

\begin{tabular}{|c|c|c|c|}
\hline & Criteria \& Descriptions & Classification & Score \\
\hline \multirow{14}{*}{$\begin{array}{l}\text { Ecological scores } \\
\qquad=(a x b)+c\end{array}$} & \multirow{5}{*}{$\begin{array}{l}\text { (a) Average mass of an } \\
\text { individual (kg) }\end{array}$} & $>500$ & 5 \\
\hline & & $50-500$ & 4* \\
\hline & & $2-50$ & 2 \\
\hline & & $0.5-2$ & 1 \\
\hline & & $<0.5$ & 0 \\
\hline & \multirow{5}{*}{$\begin{array}{l}\text { (b) Estimated } \\
\text { population using } \\
\text { Falkland Island waters } \\
\text { (number of individuals) }\end{array}$} & $>500,000$ & 5 \\
\hline & & $>100,000$ & 4 \\
\hline & & 10,000 to 100,000 & 3 \\
\hline & & $<10,000$ & 2 \\
\hline & & $<1,000$ & 1 \\
\hline & \multirow{4}{*}{$\begin{array}{c}\text { (c) Number of year } \\
\text { quarters the species } \\
\text { uses Falklands Island } \\
\text { waters }\end{array}$} & 1 & 1 \\
\hline & & 2 & 2 \\
\hline & & 3 & 3 \\
\hline & & 4 & 4 \\
\hline \multirow{4}{*}{$\begin{array}{l}\text { Criteria for Data } \\
\text { Quality scores } \\
\text { =d }\end{array}$} & \multirow{4}{*}{$\begin{array}{l}\text { (d) Data available and } \\
\text { modelling methodology }\end{array}$} & $\begin{array}{l}\text { Tracking for all colonies (in Fl and } \\
\text { overseas) known to use the } \mathrm{Fl} \text { waters }\end{array}$ & 4 \\
\hline & & $\begin{array}{l}\text { Tracking some colonies + extrapolation to } \\
>50 \% \text { colonies (if Falklands and overseas) } \\
\text { known to use Fl waters }\end{array}$ & 3 \\
\hline & & $\begin{array}{c}\text { Tracking }<50 \% \text { of colonies only, no } \\
\text { extrapolation }\end{array}$ & 2 \\
\hline & & ASO based distribution only & 1 \\
\hline \multirow{11}{*}{$\begin{array}{l}\text { Criteria for } \\
\text { Conservation } \\
\text { scores }=e+f\end{array}$} & \multirow{5}{*}{$\begin{array}{c}\text { (e) Irreplaceability } \\
\text { based on endemism and } \\
\% \text { of world population } \\
\text { using FI waters }\end{array}$} & Endemic & 5 \\
\hline & & Very high (>90\% of population) & 4 \\
\hline & & High (10-90 \% of population) & 3 \\
\hline & & Medium (1-10\% of population) & 2 \\
\hline & & Low (<1\% of population) & 1 \\
\hline & \multirow{6}{*}{ (f) IUCN threat status } & Critically endangered (CR) & 3 \\
\hline & & Endangered (EN) & $3^{\#}$ \\
\hline & & Vulnerable (VU) & 2 \\
\hline & & Near-Threatened (NT) & 1 \\
\hline & & Least Concern(LC) & 0 \\
\hline & & Data deficient (DD) & by case \\
\hline
\end{tabular}



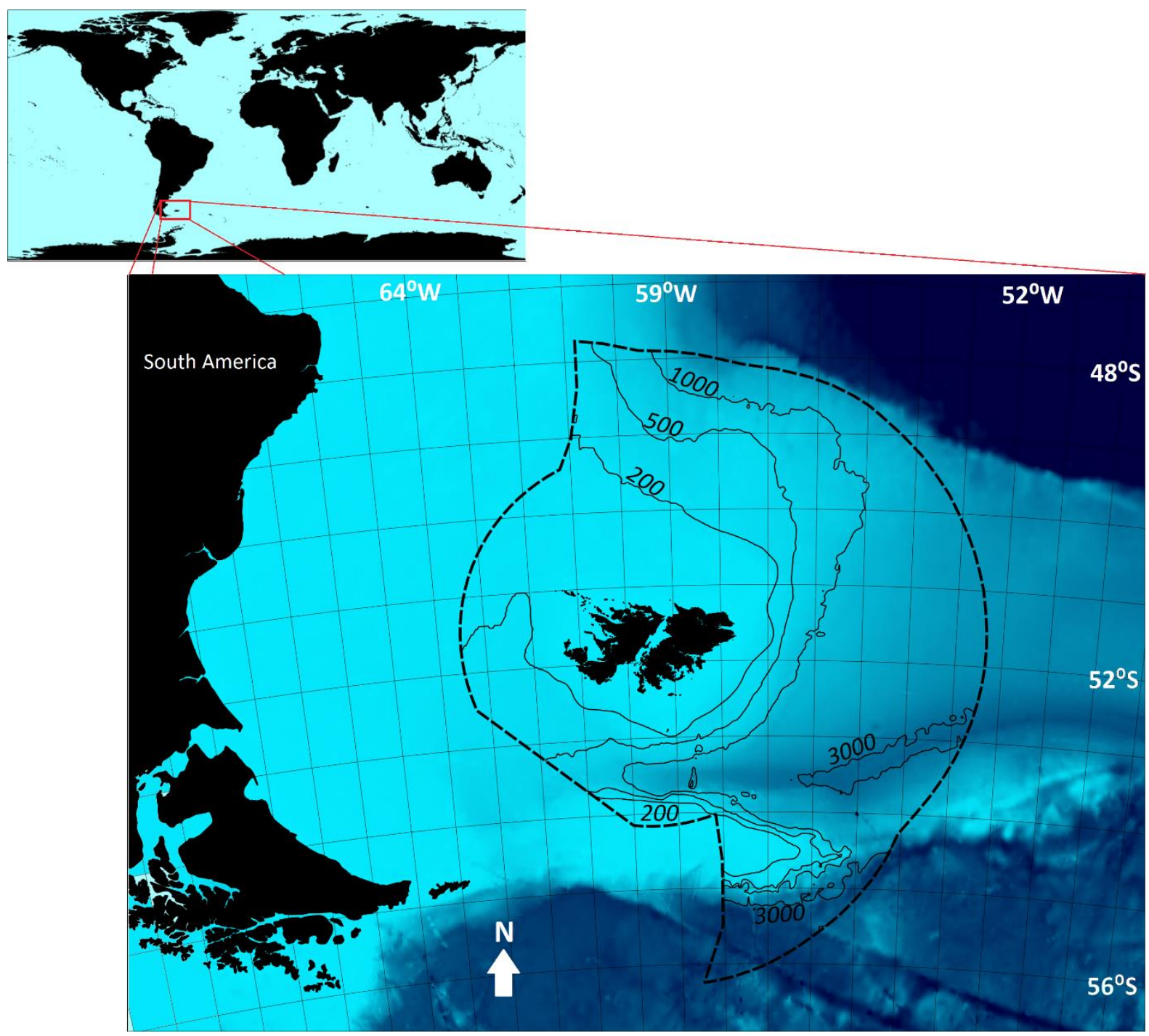

Figure 1 Location of the Falkland Islands and the study area (dashed line) on the Patagonian Shelf (lighter blue indicates shallower depths corresponding to the shelf; bathymetry contours displayed with depths). Data sources: GEBCO and Falkland Islands Fisheries Department. 


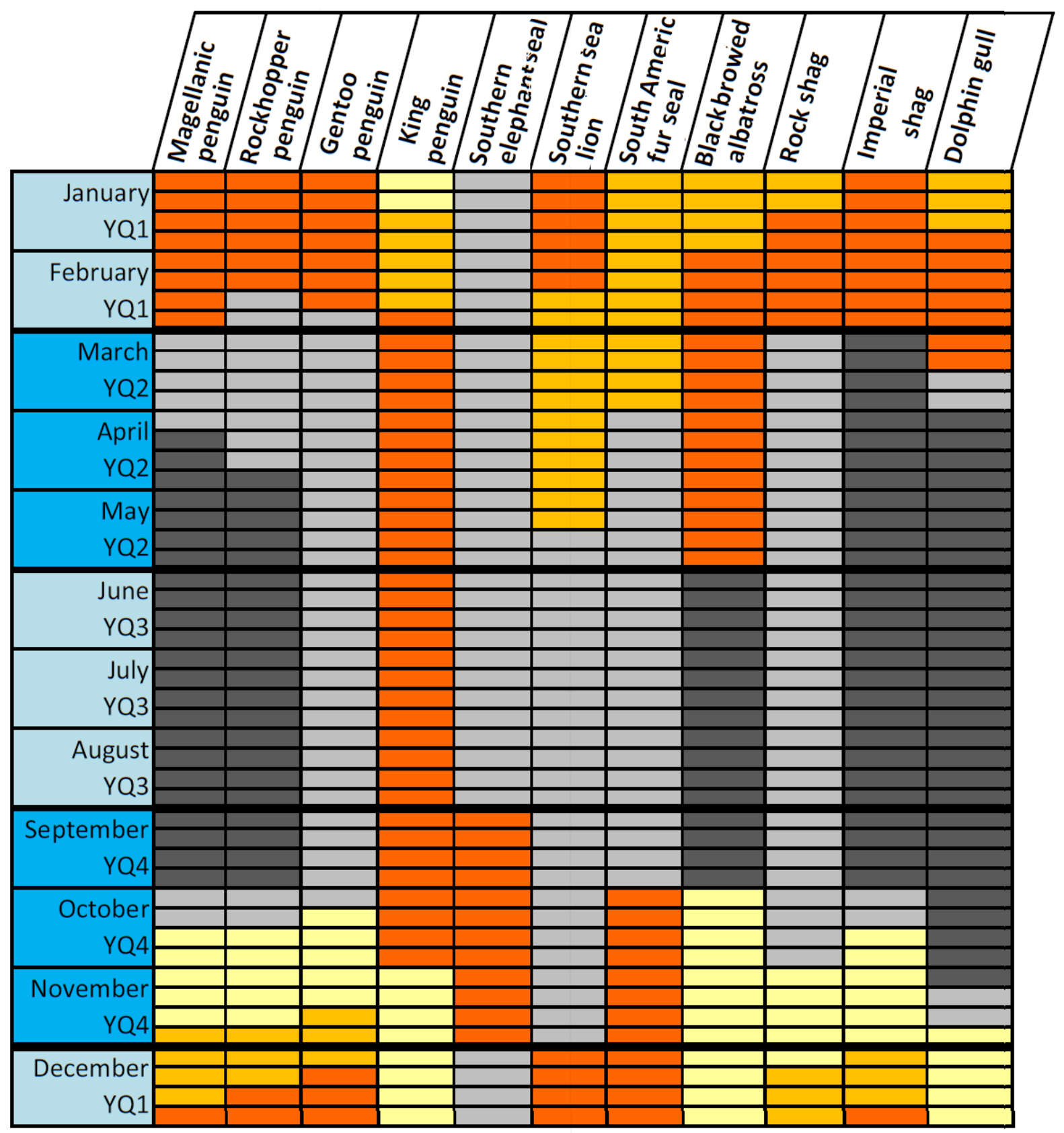

\begin{tabular}{|ll|}
\hline For seabirds & For pinnipeds \\
Not using colonies & Not using colonies \\
Using colonies & Using colonies \\
Incubation & \\
Brood-guard & Early lactation \\
Chick rearing & Mating/pupping \\
\hline
\end{tabular}

Figure $\mathbf{2}$ Annual life cycle stages of the species where tracking data was available in the Falklands' waters. YQ: year-quarter. 


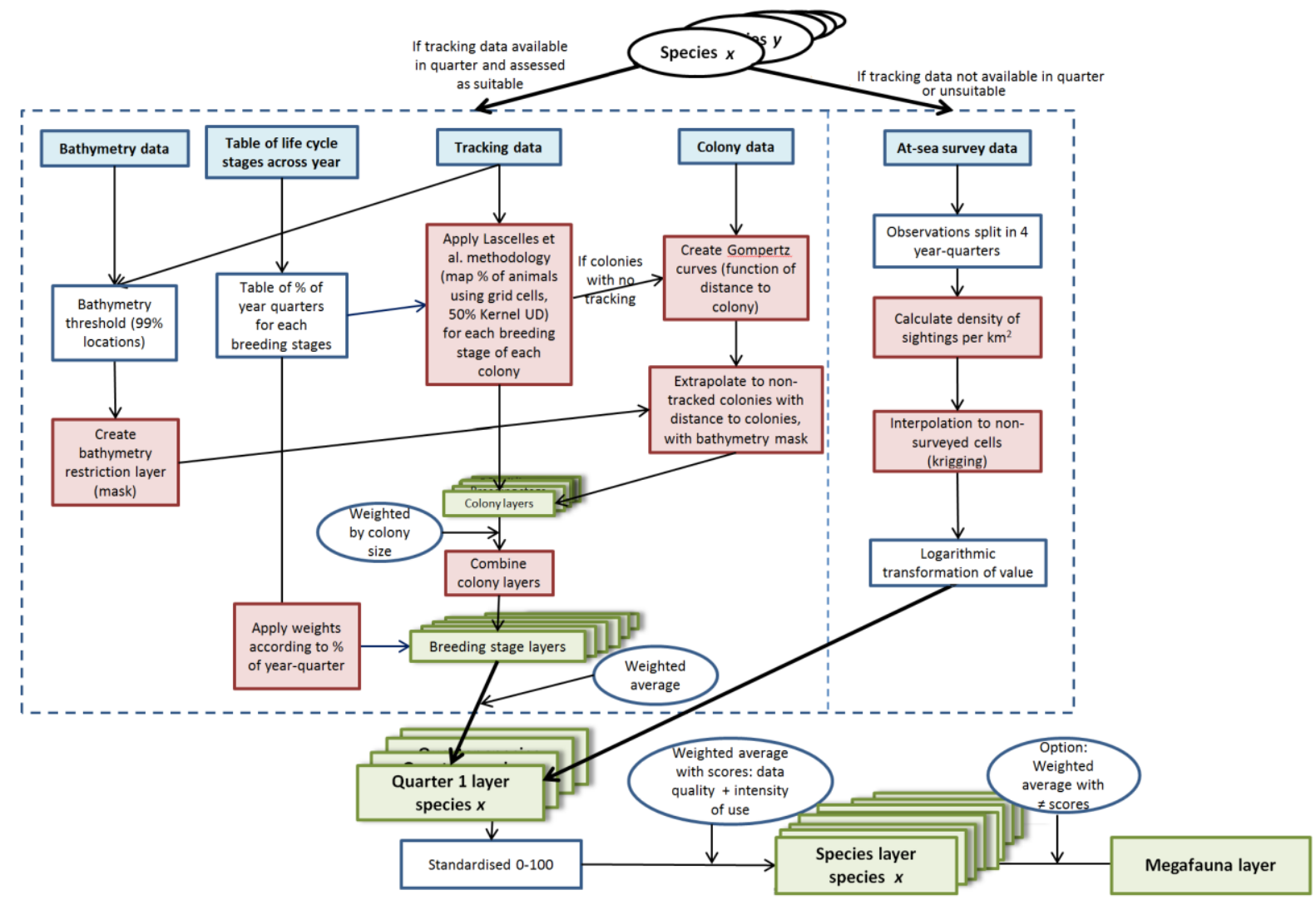

Figure 3 Methodological framework to map key areas for marine megafauna 


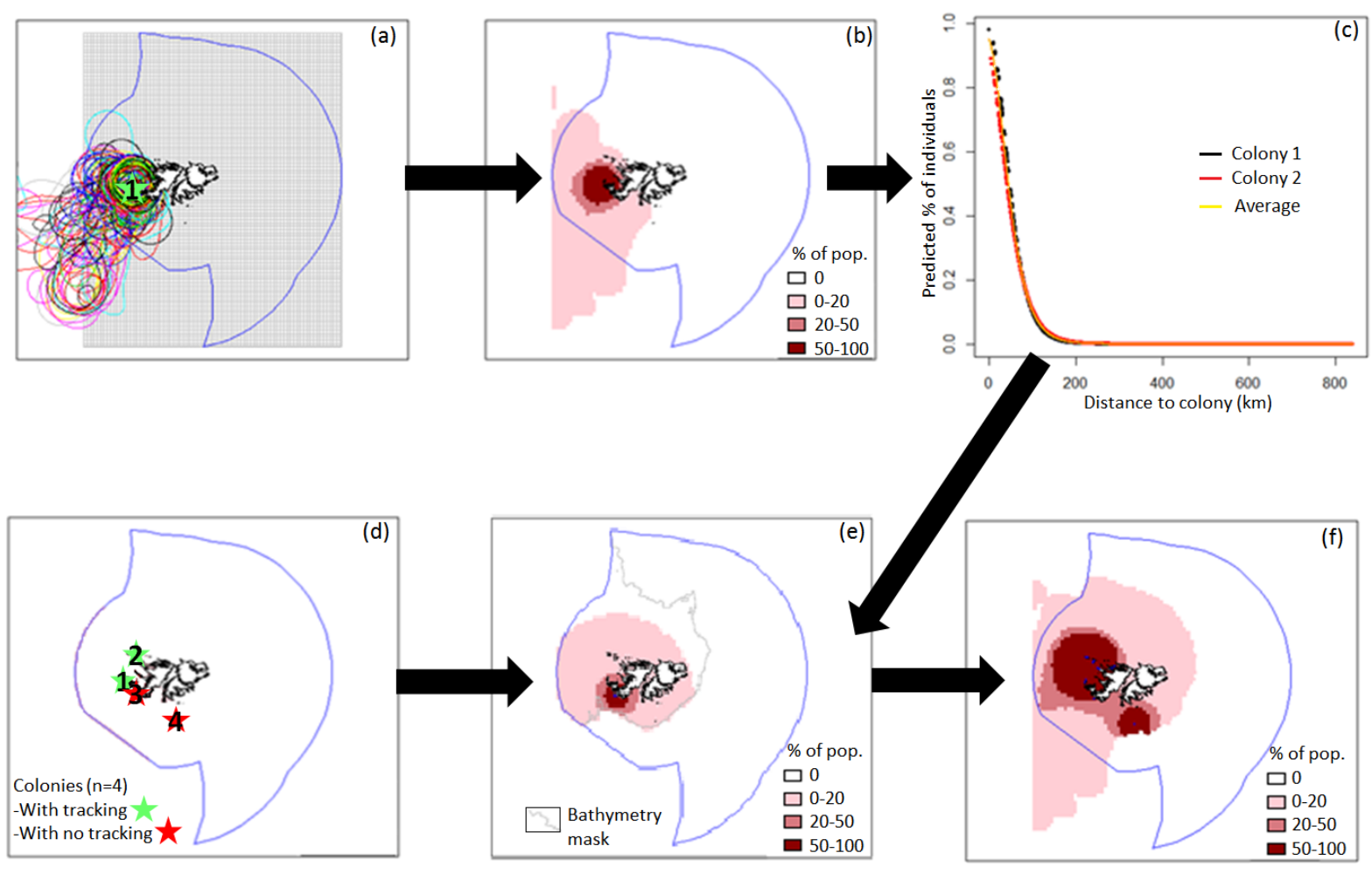

Figure 4 Illustration of the methodology to produce the species quarter layers using the example of the black-browed albatross during the brood-guard stage (tracking data source: Falklands Conservation, J.P. Granadeiro, P. Catry). (a) Core-use areas (50\% Kernel utilisation distribution) for each individual track as per methodology in Lascelles et al. (2016) from colony 1, (b) \% of core-use area found in each cell for colony 1 from tracking data (c) Relationship between $\%$ of core-use areas and distance to colony (Gompertz Curve), (d) location of 4 example breeding colonies, (e) extrapolated colony layer for colony 3 , (f) breeding stage layer for the species accounting for all colonies weighed by colony numbers. 


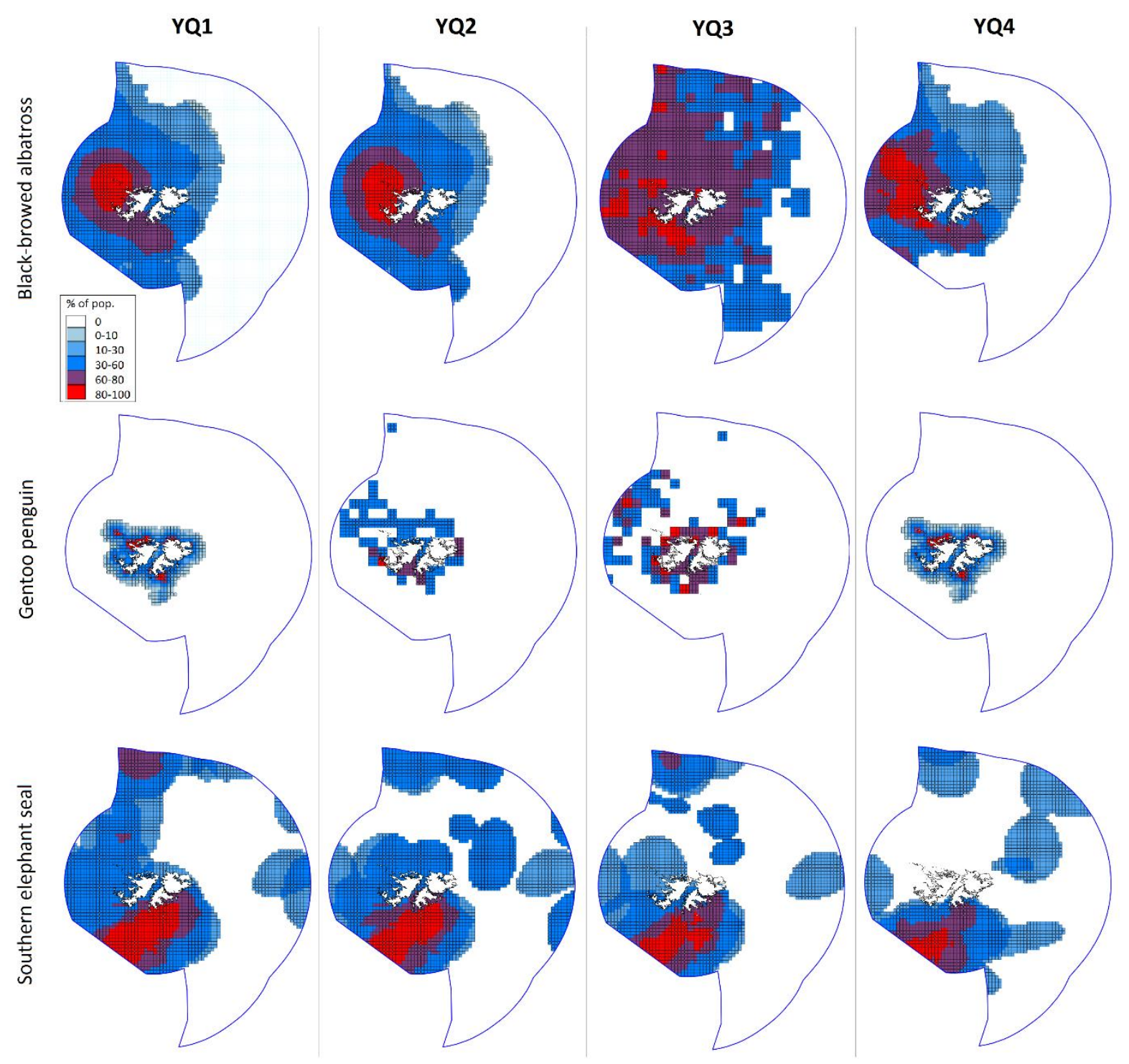

Figure 5 Examples of the 4 quarter layers for 3 species for each year quarter (YQ1: Dec-Feb (summer), YQ2: Mar-May (autumn),YQ 3: Jun-Aug (winter), 4: Sep-Nov (spring)), black-browed albatross (data quality for YQ1 and YQ2: tracking + extrapolation; YQ3: ASO only; YQ4: tracking only), Gentoo penguin (data quality for YQ1 and 4: tracking + extrapolation; YQ 2 and 3: ASO only), and southern elephant seal (data quality all tracking only). 


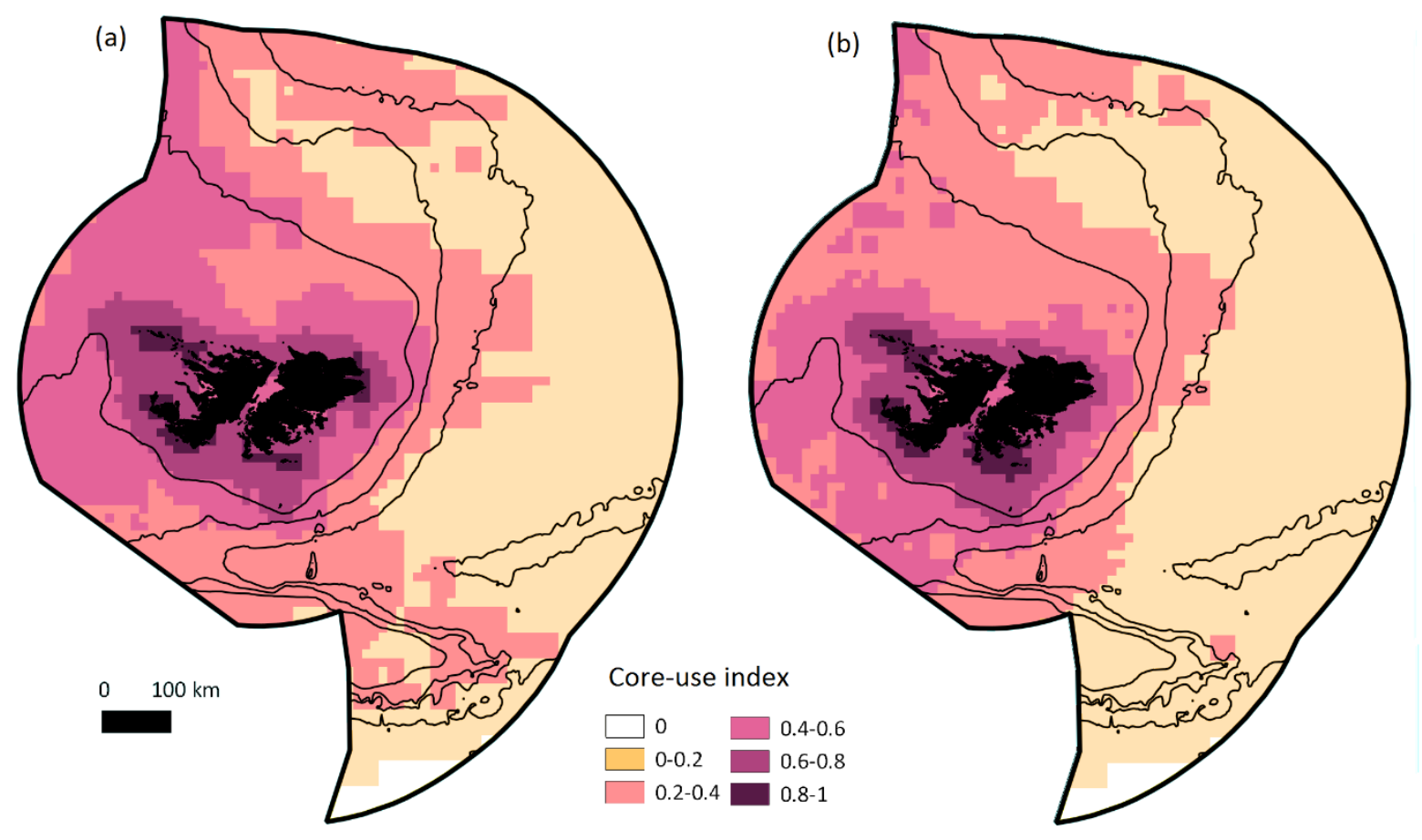

Figure 6 Core-use areas by marine megafauna In the Falkland Islands Economic Exclusive Zone; a) with conservation scores and b) with ecological scores 


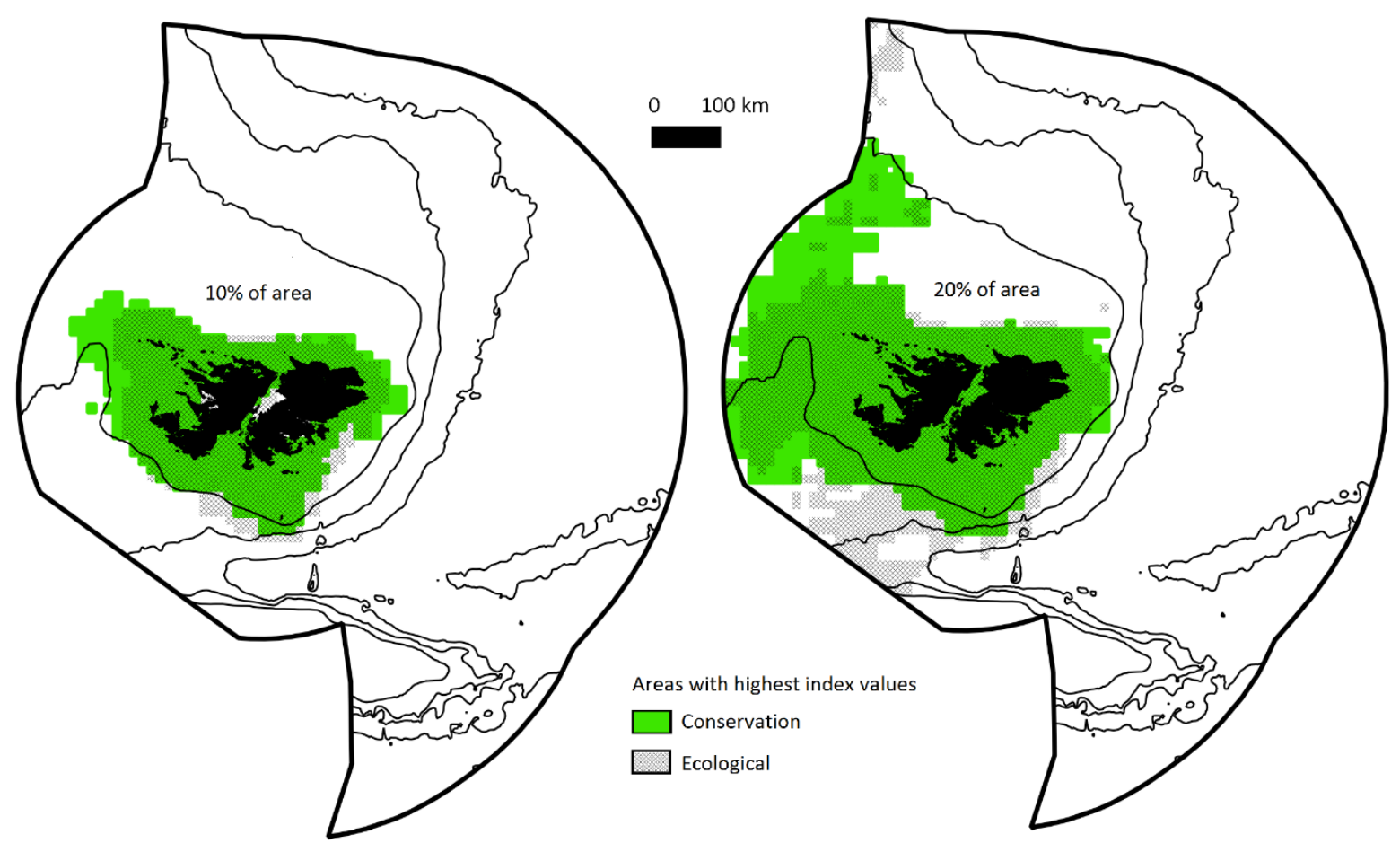

Figure 7 Areas with the highest marine megafauna core-use index values with conservation and ecological scores, for $10 \%$ of the Falkland Islands Economic Exclusive Zone) left) and for $20 \%$ of this EEZ (right) 


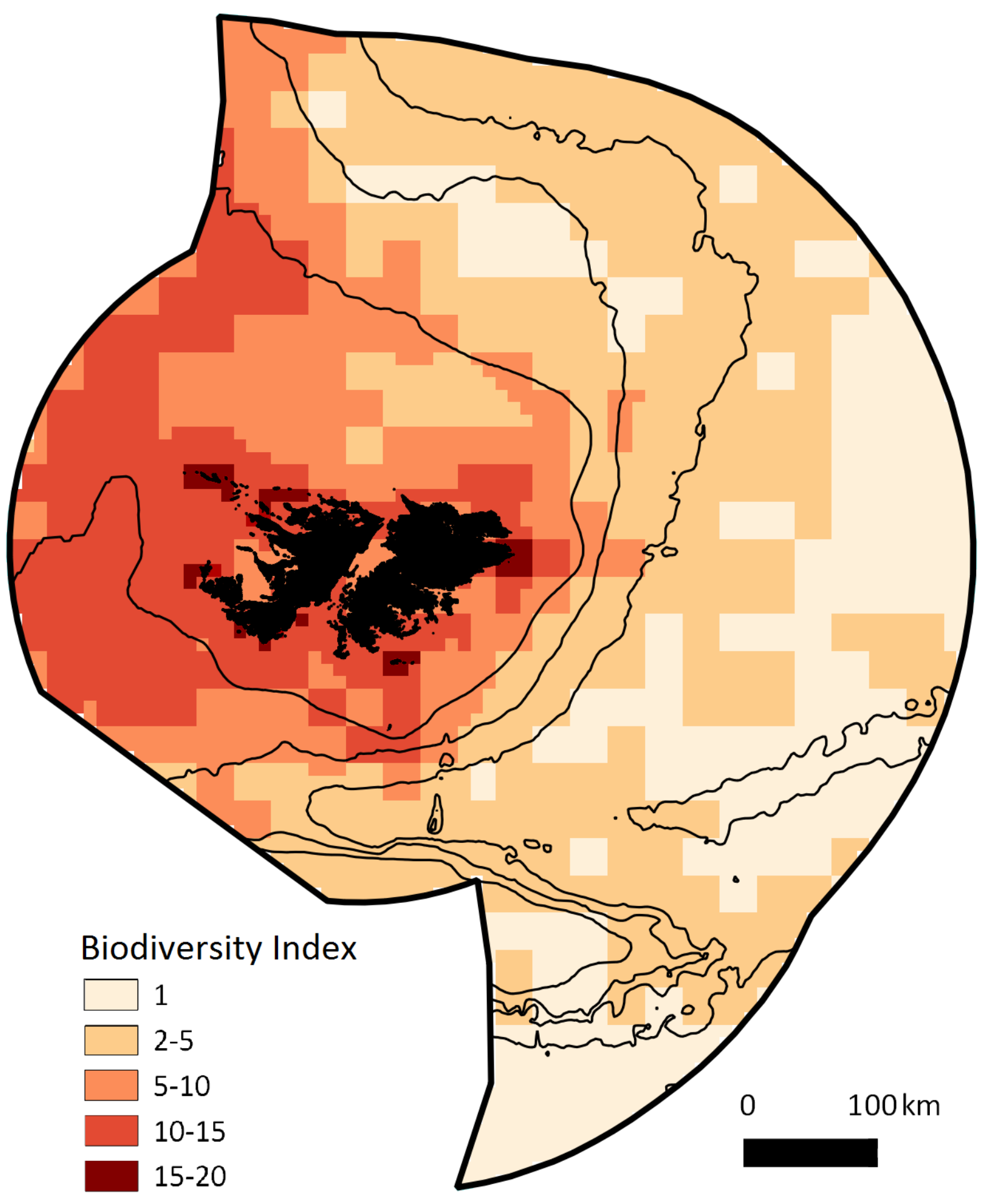

Figure 8 Map of megafauna species richness displayed as the biodiversity index in the Falkland Islands Economic Exclusive Zone. The index is the number of species' core-use areas (50\% Kernel distribution) out of the 36 study species including in the analysis that are contained within each $10 \mathrm{~km}$ cell. 